\title{
A legitimidade ativa do Ministério Público na Ação Civil Pública
}

Alessandra Mendes"

SUMÁRIO: 1. Introdução. 2. Ministério Público como autor. 3. Ministério Público como fiscal da lei. 4. Ministério Público en caso de abandono ou desistência. 5. Ministério Público estadual e federal: litisconsórcio. 6. Conclusóes. 7. Bibliografia.

SUMMARY: 1. Introduction. 2. State Attoney as author. 3. State Attorney as inspector of the law. 4. State Attorney in case of abandonment or waiver of an action. 5. State Attorney and Federal Attorncy: jointer of parties. 6. Conclusion. 7. Bibliography.

SUMARIO: 1. Introducción. 2. Ministério Público como autor. 3. Ministério Público como fiscal de la ley. 4. Ministério Público en caso de abandono o cesación de la acción. 5. Ministério Público Estataly Federal: litisconsórcio. 6. Conclusión. 7. Bibliografía.

RESUMO: Com o objetivo de aprofundar o estudo e o debate de regras processuais que vêm sendo utilizadas nas açóes coletivas, o presente trabalho elegeu o tema da legitimidade ativa do $\mathrm{Mi}$ nistério Publico na Ação Civil Pública. Foram abordadas as questões relativas ao Ministério Publico como autor, como fiscal da lei, no caso de abandono ou desistência da ação civil pública e, finalmente, a polêmica possibilidade da atuação conjunta entre o Ministério Público Estadual e Federal.

ABSTRACT: The present study has the objective to debate $i-$ vil procedural rules and how they have been used in the collective actions, the present work chose the theme of the legitimacy it

Mestranda en Direito Negocial pela Universidade Estadual de Londrina. 
activates of the Ministry I Publish in the Public Civil Action. The relative subjects were approached to the Ministry I Publish as author, as fiscal of the law, in the case of abandonment or cessation of the public civil action and, finally, the controversy possibility of the united performance among the State and Federal public prosecution service.

RESUMEN: Con el objetivo de ahondat el estudio y el debate de reglas procesales que son usadas en las acciones colectivas, el presente trabajo escogió el tema de la legitimidad activa del Ministerio Publico en la Acción Civil Pública. Los asuntos escöidos fueram: Ministerio Publico como el autor, como fiscal de la ley, en el caso de abandono o cesación de la acción civil pública y, finalmente, la controversia de la actuación unida entre el servicio de la prosecución público Estatal y Federal.

PALAVRAS-CHAVE: Legitimidade ativa. Ministério Público. Ação Civil Pública.

KEY-WORDS: Activelegitimacy. State Attoney. Public Civil Action.

PALABRAS-LLAVE: Legitimidad activa. Prosecución Público. Acción Civil pública.

\section{Introdução}

Os legitimados ativos à propositura da ação civil pública são aqueles que integram o rol do artigo $5^{\underline{a}}$ da Lei n. ${ }^{\underline{a}}$ 7.347/85 (Lei da Ação Civil Pública), bem como os entes enumerados no artigo 82 da Lei n. $8.078 / 90$ (Código de Defesa do Consumidor).

É importante destacar que a Lei n. ${ }^{\text {a }} 7.853 / 89$, que dispóe sobre $\mathrm{o}$ apoio às pessoas portadoras de deficiência, dentre outras providências, traz em seu artigo $3^{\underline{a}}$ praticamente os mesmos órgãos e entidades previstas como legitimados na Lei n. ${ }^{-} 7.347 / 85$, com a ressalva de que tais entidades e órgãos incluam entre suas finalidades a proteção às pessoas portadoras de deficiência.

Não se pode olvidar também do artigo $1^{\underline{a}}$ da Lei n. $7.913 / 89$, que dispõe sobre a ação civil pública de responsabilidade por danos causados aos investidores no mercado mobiliário, que concede legitimidade ao Ministério Público para propor tais ações. 
E finalmente, tem-se também a Lei n. ${ }^{\text {a }}$ 8.069/90, que dispõe sobre o Estatuto da Criança e do Adolescente e que, ao tratar em seu artigo 210 dos legitimados à propositura da ação civil pública para a tutela dos direitos dos infantes, arrola não só o Ministério Público, como também a União, os Estados, os Municípios, o Distrito Federal, os Territórios e as associações legalmente constituídas há pelo menos um ano e que incluam entre seus fins institucionais a defesa dos interesses e direitos protegidos pelo Estatuto da Criança e do Adolescente, ressalvando que será dispensada a autorização da assembléia desde que haja prévia autorização estatutária.

Assim sendo, de acordo com os dispositivos supramencionados, são legitimados a propor a ação civil pública: i) o Ministério Público; ii) a União, os Estados e os Municípios; iii) as Autarquias, as Empresas Públicas, as Fundações e as Sociedades de Economia Mista; iv) as associações; v) as entidades e órgãos da administração pública, direta ou indireta, ainda que sem personalidade jurídica.

O presente estudo elegeu como tema central a legitimidade ativa do Ministério Público.

O Ministério Público, segundo o artigo 127 de nossa Carta Magna, é “instituição permanente, essencial à função jurisdicional do Estado, incumbido-lhe a defesa da ordem jurídica, do regime democrático de direito e dos interesses sociais e individuais indisponíveis”.

Em razão de sua estruturação e do grau de qualificação de seus membros, o Ministério Público é tido por alguns como o mais bem preparado dos legitimados à defesa dos interesses coletivos. E os números também têm demonstrado essa importância, pois é notório que a maioria das ações civis públicas ajuizadas até o momento foi proposta pelo Ministério Público.

Sobre o tema, João Batista de Almeida teve oportunidade de se pronunciar na forma que segue:

Em face de suas atribuições constitucionais de defesa da sociedade e dos interesses sociais e individuais (CF, art. 127, c/c art. 129, II e III) e da qualificação profissional de seus membros, o Ministério Público, dentre os demais legitimados, é, certamente, o órgão mais bem aparelhado para promover a defesa dos direitos ou interesses difusos, coletivos e individuais homogêneos, em nível judicial. Há, verdadeiramente, uma vocação natural para o mister, o que explica o grande volume de ações propostas pelo Parquet sobre a matéria. ${ }^{1}$

${ }^{1}$ ALMEIDA, J. B. Aspectos Controvertidos da Ação Civil Pública. São Paulo: Revista dos Tribunais, 2001, p.96. 
$\mathrm{O}$ fato de os demais legitimados à propositura da ação civil pública não serem tão ativos empiricamente como o Ministério Público pode ser explicado pela própria história da nação brasileira, em que a experiência democrática é ainda muito recente, não sendo poucos os que se recordam do período ditatorial em que os segmentos sociais, empresariais e políticos não tinham qualquer liberdade de expressão.

Acredita-se que o próprio exemplo do Ministério Público ao ajuizar inúmeras ações civis públicas em defesa dos interesses coletivos vem resgatando a consciência de toda a sociedade, fazendo-a perceber que nossa legislação já é capaz de coibir desmandos e injustiças que no passado se quedavam impunes.

Contrário a este entendimento, há vozes na doutrina que criticam a atuação do Parquet em sede de açôes coletivas. Argumentam que a estrutura do órgão ministerial encontrar-se-ia demasiadamente inserida no Poder Executivo, o que lhe retiraria a liberdade e independência.

Mas, como bem explica Rodolfo de Camargo Mancuso:

Tais críticas podem, quiçá, ser válidas para outros países, mas não se aplicam, a toda a evidência, ao Ministério Público em nosso País, instituição una e indivisivel, permanente e essencial à função jurisdicional do Estado, vocacionada à defesa da ordem jurídica, do regime democrático e dos interesses sociais e individuais indisponíveis. ${ }^{2}$

Assim sendo, como já exposto, as críticas ao Ministerio Público não devem prosperar.

Isso porque, a partir da Constituição Federal de 1988, o Ministério Público teve reconhecido status de maior importância no cenário nacional, tendo sido ampliados os seus poderes e prerrogativas, o que the deu autonomia e independência no exercício de suas funçōes (art. 127, $§ 1^{2}, \mathrm{CF} / 88^{3}$ ).

Nesse sentido, Alexandre de Moraes leciona que:

A Constituição Federal de 1988 ampliou sobremaneira as funções do Ministério Público, transformando-o em um verdadeiro defensor da sociedade, tanto no campo penal, com a titularidade exclusiva da ação penal pública, quanto no campo ć́vel, como fiscal dos demais Poderes públicos e defensor da legalidade e moralidade administrativa, inclusive com a titularidade do inquérito civil e da ação civil pública.

\footnotetext{
"MANCUSO, R. C. Aço Cinit Priblica em defesa do Meio Ambiente, do Patrimonio Cultual e dos Consumidores. $7^{a}$ ediçâo, sâo Paulo: Revista dos Tribunais, 2001, p. 106.

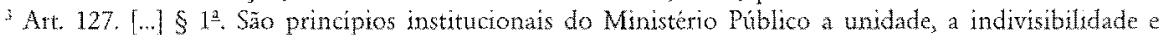
a independência funcional.

'MOARES, Alexandre de. Direito Constitucional. 11* edição, São Paulo: Editora Attas, 2002.
} 
Para se ter idéia acerca da importância da autonomia do Ministério Público conferida pela Constituição de 1988, a própria Carta dos Povos considera crime de responsabilidade do Presidente da República qualquer ato atentatório ao livre exercício da instituição, consoante previsão expressa trazida pelo art. 85, inciso II da Constituição Federal, demonstrando sua patente independência em relação a quaisquer dos Poderes constituídos do Estado brasileiro, dentre eles o Poder Executivo.

Destacada a importância do Ministerio Público na tutela de direitos coletivos, passa-se a discorrer sobre as diferentes hipóteses em que o órgão ministerial poderá atuar em sede de ação civil pública.

\section{Ministério Público como autor}

Como mencionado do item anterior, o Ministério Público é um dos entes legitimados ao ajuizamento da ação civil pública.

Questiona-se na doutrina se, devido às suas finalidades institucionais, o Ministerio Público estaria obrigado a ajuizar ações civis públicas ou se o promotor público teria discricionariedade no caso de ter conhecimento de algum fato lesivo ao meio ambiente, ao consumidor, ao patrimônio histórico-cultural, à ordem urbanística, à ordem econômica ou a qualquer outro interesse difuso ou coletivo.

Os mais radicais levantam a hipótese até mesmo de crime de prevaricação, conforme artigo 319 do Código Penal, para o caso de omissão do Ministério Público quanto ao ajuizamento da ação civil pública.

Não parece ser esse o melhor entendimento, pois como bem asseverado por Pedro da Silva Dinamarco:

Entretanto, não está o Ministério Público necessariamente obrigado a ajuizar a demanda coletiva. Conforme corrente majoritária, ele tem liberdade para vislumbrar a existência de interesse público a legitimar a sua atuação. Se se omitir, porém, nenhuma penalidade poderá ser imposta à instituição ou a qualquer de seus agentes, em razão do princípio constitucional da independência, salvo quando demonstrada a caracterização de dolo, inadmitindo-se a caracterização de crime por mera culpa. ${ }^{5}$

Vale ressaltar, ainda, que no caso da ação civil pública, ao contrário da ação penal pública, o Ministério Público é apenas um dos co-legitimados, restando ainda um leque de outros entes que também possuem legitimidade para o ajuizamento da competente ação.

DINAMARCO, P. S. Açio Cinl Publica. Săo Paulo: Saraiva, 2001, p.210. 
É claro também que, constatado o efetivo dolo do parquet na ocultação de algum fato para privilegiar terceiros, por certo, caberá sua responsabilização por isso, seja no âmbito administrativo, seja no cível ou até mesmo no penal.

A respeito do tema Hugo Nigro Mazzilli entende que:

Essa obrigatoriedade deve ser bem compreendida. Não se admite que o Ministério Público, identificando uma hipótese em que deva agir, recusese a fazê-lo: nesse sentido, sua ação é um dever. Com efeito, bem apontou Calamdrei que, se o Ministério Público adverte ter sido violada a lei, não se admite que, por razões de conveniência, se abstenha de acionar ou de intervir para fazer com que restabeleça a ordem legal. Naturalmente, essa lição não há de aplicar-se às hipóteses em que a própria lei lhe confira a possibilidade de agir sob critérios discricionários. ${ }^{6}$

A sobreposição da independência funcional do membro do Ministério Público em relação à indisponibilidade da ação civil pública não é, entretanto, absoluta. Por certo, uma vez ajuizada a demanda coletiva, entende-se não poderá mais o Ministério Público desistir da ação, em virtude da relevância e magnitude dos direitos tutelados.

Apesar da falta de vedação legal expressa nesse sentido ${ }^{7}$, ousa-se entender, portanto, que a ação civil pública não é disponível ao Ministério Público depois de ajuizada, ou seja, assim como na ação penal pública (art. 42, $\mathrm{CPP})$, também na ação civil pública não poderá o Ministerio Púbico desistir da ação após o seu ajuizamento, uma vez que o Ministério Público não é o verdadeiro titular dos direitos tutelados, não poderá deles dispor.

Nesse sentido, Teori Albino Zavascki aduz:

Decerto inaceitável o argumento o qual, por não ser vedada em lei, a desistência, pelo Ministério Público, estaria permitida. Se a regra vale para o particular, o mesmo não se dá em relação ao Ministério Público que, como órgão do Estado que é, obedece a regra básica do direito público: os agentes do Estado somente podem praticar atos para os quais estejam autorizados por norma legal válida. Não bastaria, portanto, ausência de proibição, como ocorre na atividade dos particulares. A atuação do Ministério Público é vinculada não à vontade pessoal de seus agentes, mas a uma finalidade impessoal e pública, definida em lei. ${ }^{8}$

Apesar de a desistência da ação implicar extinção do feito sem julgamento de seu mérito (art. 267, inciso VIII, CPC), sendo situação ontologicamente distinta da renúncia ao direito sobre o qual se funda a

\footnotetext{
"MAZZLLL, H. N. A defesa dos interesses difusos en inzo. 13" edição, São Panlo: Sarana, p.2001, p.78. "Vcia-se que, no caso das aços diretas de inconstitucionalidade, a legislaçä́ ce expressa ao vedar a

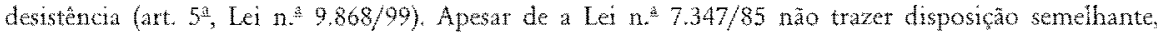
entende-se no mesmo sentido da vedaçấo.

"ZAVASCKI, T. A. O Ministerio Público e Açäo Civil Pública. Revista n." 114, ano 29,1992, p.155.
} 
ação, que resulta na extinção do processo com análise meritória (art. 269 , inciso $\mathrm{V}, \mathrm{CPC}$ ), a desistência da ação pressupõe expressa concordância do titular do direito material invocado. É a conclusão a que se chega da leitura do artigo 38 do diploma processual citado que, ao lado da renúncia do direito, coloca a desistência da ação dentre as situações que exigem do advogado poderes especiais para atuar em juizo.

Por tais motivos, entende-se que o Ministério Público não pode desistir da ação civil pública após intentada, além de não poder, igualmente, dispor de outros direitos processuais que afetem diretamente o direito material daqueles que serão atingidos pelo resultado da demanda."

Outro aspecto que vem gerando uma certa polêmica na doutrina e na jurisprudência refere-se à natureza dos interesses que poderão ser tutelados pelo Ministério Público, já que a Constituição, em seu artigo 129, inciso III, somente mencionou os interesses difusos e coletivos, não fazendo qualquer alusâo aos interesses individuais homogêneos.

Ocorre que, tecendo-se uma interpretação sistemática do texto constitucional, verificamos no caput de seu art. 127 que compete ao Ministério Público a defesa "dos interesses sociais e individuais indisponíveis", ao mesmo tempo em que o legislador constitucional atribuiu igualmente ao Ministério Público, em seu artigo 129, inciso IX ${ }^{10}$ " "exercer outras funçôes que the forem conferidas, desde que compativeis com sua finalidade".

Assim, não se vê óbice à tutela coletiva de direitos individuais por parte do Ministério Público.

Tanto o Supremo Tribunal Federal ${ }^{11}$ como Superior Tribunal de Justi$\mathrm{ça}^{12}$ já decidiram no sentido de estender a legitimidade do Ministério

\footnotetext{
"A questão da disponibilidade da ação civil pública seráa analisada con mais acuidade no tópico 8.2.1.2 deste trabalho, mais adiante.

1" Art. 129, CF: São hunçôes institucionais do Ministério Público: (...) LX - exercer outras funçốes que the forem conferidas, desde que compativeis com sua finalidade, sendo the vedada a representaça judicial c a consultona juridica de entidades públicas.

1 RE 204200 AGR / SP - SAOO PAULO, AG.REG.NO RECURSO EXTRAORDINÁRIO, Relator(a): Min. CARLOS VELLOSO, Julgamento: Segunda Turma, EMENTA: CONSTITUCIONAL. ACÃO CIVIL PÚBLICA: MINISTERIO PÚBLICO: DIREITOS NDDVIDUAIS HOMOGENEOS. Lei 7.374/85, art. 1*, II, e art. 21, com a redação do art. 117 da Lei 8.078/90 (Código do Consumidor) Lei 8.625/93, art. 25. C.F., artigos 127 e 129, III. I. - Ação civil pública que teta por objeto direitos individuais homogêneos: legitimidade ativa do Ministétio Público: questão que se situa no campo infraconstitucional: Lei $7.374 / 85$, art. $1^{12}$, II, art. 21 , redação do ant. 117 e arts. 81 e 82 da Lei $8.078 / 90$ (Código do Consumidor); Lei $8.625 /$ 93, art. 25. II. - Questio constitucional do art. 129 , III, não invocada. II. - Direitos individuais homogèneos, decorrentes de contratos de compromisso de compra e venda que năo se identificam com "interesses sociais e individuais indisponives" (C.F., art. 127). IV. - Agravo regimental nâto provido.

2 RESP 404239/PR; Recurso Especial, 2001/0191186-2, data: 19/12/2002, p. 00367, Rel. Ruy Rosado de Aguiar. ACAO CIIL PÚBLICA. Ministério Público. Legitimidade. Contrato para aquisiça de casa propria. O Ministério Público tem legitimidade para promover aça civil pública em defesa de interesses individuats homogeneos presentes nos contratos de compra e venda de imóveís de conjuntos habitacionats, pelo sistema financeiro da habitaçăo, ama vez evidenciado interesse social relevante de defesa da economia popular. Precedentes. Recurso năo conhecido.
} 
Público em caso de direitos individuais homogêneos, limitando-a apenas aos casos em que estes se referissem a direito social ou indisponivel.

Todavia, na prática não é muito simples reconhecer quais são os direitos indisponiveis, apesar de a doutrina trazer definições, como é o caso de Miguel Reale: "são direitos indisponíveis aqueles que, por sua natureza essencial ao valor e à sobrevivência da pessoa humana ou ao bem da coletividade, não poderão ser objeto de renúncia, de troca ou de cessão a terceiros". ${ }^{2}$

$\mathrm{Na}$ tentativa de pacificar o entendimento, o Conselho Superior do Ministério Público paulista editou a Súmula n. 7 , exemplificando os casos em que o Parquet teria legitimidade para ajuizar ação civil pública na tutela de direitos individuais homogêneos. Veja-se:

O Ministério Público está legitimado à defesa de interesses individuais homogêneos que tenham expressão para a coletividade, como: a) os que digam respeito à saúde ou à segurança das pessoas, ou ao acesso das crianças e adolescentes à educação; b) aqueles em que haja extraordinária dispersão dos lesados; c) quando convenha à coletividade o zelo pelo funcionamento de um sistema econômico, social ou jurídico.

Verifica-se que a legitimidade do Ministério Público para a propositura da ação civil pública, quando envolva direitos individuais homogêneos, advém de um interesse geral da sociedade nas soluções dos litígios.

Portanto, a análise da legitimidade do Ministério Público nessas hipóteses deverá ser realizada caso a caso, não se justificando, por exemplo, que um promotor de justiça saia em defesa dos interesses de apenas alguns indivíduos quando tais interesses não ofereçam qualquer repercussão à sociedade.

Com efeito, conclui-se que o Ministério Público, além da legitimidade que lhe deu a própria constituição federal para tutelar direitos difusos e coletivos (art. 129, inciso III), poderá igualmente tutelar coletivamente direitos individuais homogêneos indisponiveis ou, apesar de sua disponibilidade, direitos individuais homogêneos que sejam socialmente relevantes (art. 127, caput, Constituição Federal de 1988).

Por outro lado, parece ser importante transcrever entendimento em sentido contrário ao aqui adotado, como é o caso daquele lecionado por Luiz Rodrigues Wambier:

Há, todavia, ao nosso ver, um óbice intransponível para a admissão da legitimidade do Ministério Público, em se tratando de demandas relativas 
aos direitos individuais homogêneos. Trata-se do dispositivo a que nos referimos algumas linhas atrás, e que está contido no inc. III do art. $129 \mathrm{da}$ Constituição Federal. [...] É certo que - em relação à legitimidade do Ministério Público - onde o legislador constituinte a omitiu, não quis inclú1a. Nem mesmo os esforços de interpretação dos organismos superiores do Ministério Público, como é o caso do Conselho Superior do Ministério Público, parecem suficientes para ampliar a sua legitimidade. ${ }^{14}$

Dada a devida vênia, a adoção de uma interpretação sistemática da Carta Magna permite concluir que, apesar de não ter previsto expressamente em seu artigo 129, inciso III a defesa pelo Ministério Público de direitos individuais homogêneos, expressamente o previu no caput do artigo 127, desde que indisponíveis ou de relevante interesse social.

\section{Ministério Público como fiscal da lei}

De acordo como o $\$ 1^{\text {a }}$ do artigo $5^{\text {a }}$ da Lei n. ${ }^{-}$7.347/85, nos casos em que o Ministério Público não intervier no processo como parte, atuará obrigatoriamente como fiscal da lei.

Primeiramente, é importante destacar que a redação dada pelo legislador ao dispositivo legal acima transcrito não foi tecnicamente a mais correta, pois, seja atuando como autor, seja como fiscal da lei, o Ministerio Público será parte no processo, pois para isso basta que ele esteja sujeito ao contraditório.

Na realidade, o que o texto legal tentou expressar foi que, nas hipóteses em que o Ministério Público não for o autor (e não parte, como diz o texto legal) da ação civil pública, deverá intervir no feito na qualidade de fiscal da lei.

Rodolfo de Carmargo Mancuso, partilhando do mesmo entendimento aduz:

Com efeito todo aquele que está presente no contraditório perante o juiz é parte. Portanto, dizer que o Ministério Público ora é parte ora é fiscal da lei não define uma verdadeira distinção de atividades, porque seja como autor ou como réu, seja como interveniente eqüidistante a autor e réu, o Ministério Público, desde que participante do contraditório, também é parte. ${ }^{15}$

Acrescenta ainda Pedro da Silva Dinamarco ${ }^{16}$ que ser parte significa ser titular de deveres, ônus, poderes e faculdades, posições estas de que é titular o Ministério Público, seja quando atua na condição de autor, seja como na de fiscal da lei.

\footnotetext{
14 WAMBIER, L. R, Liquhąo de Sentenca Sao Paulo: Revista dos Tribunais, 1997, p. 236-239.

15 MANCUSO, op. cit, p. 120

* DINAMARCO, op cit, p.228
} 
Em sua atuação como custos legis o Ministério Público não está obrigado a emitir parecer em sentido favorável ao autor da demanda, sob pena de ofensa à garantia constitucional de independência e autonomia, prevista no artigo 127, $\S \S 1^{\underline{a}}$ e $2^{\underline{a} 17}$ já mencionados. Aliás, se assim o fosse, o Ministério Público atuaria como litisconsorte do autor, e não como fiscal da lei.

Assim, a participação do Ministério Público como fiscal da lei nos casos em que não atua como autor é de sobremaneira importância, pois, como é sabido, as matérias versadas em sede de ação civil pública são de interesse de toda a sociedade, não sendo raras as tentativas de simulações ou colusões entre as partes do processo com o intuito de minar a eficácia de seu julgado.

$\mathrm{Na}$ condição de fiscal da lei o Ministério Público terá vista dos autos após as partes, devendo ser intimado de todos os atos realizados no processo, podendo ainda juntar documentos, certidões, produzir provas em audiência e requerer diligências que entender necessárias à solução do feito, tudo sob pena de nulidade processual, conforme disposição do artigo 83 do Código de Processo Civil, aplicado subsidiariamente por força do disposto no artigo 19 da Lei n. $\stackrel{\text { a }}{7.347 / 85}$.

Em verdade, a previsão trazida pelo artigo $5^{\mathrm{a}}$, $\S 1^{\mathrm{a}}$ da Lei n. ${ }^{\mathrm{a}} 7.347 / 85$ nada mais foi do que uma forma de enfatizar a previsão já constante do Código de Processo Civil, em seu artigo 82, inciso III, eis que, via de regra, os direitos tutelados coletivamente se subsumem ao conceito de "interesse público evidenciado pela natureza da lide".

A doutrina tem questionado sobre a necessidade de intervenção do Ministério Público nos casos em que for igualmente o autor da demanda. Ao terem oportunidade de se manifestar sobre o assunto, os tribunais vêm decidindo no sentido de dispensar tal intervenção. ${ }^{18}$

O entendimento acima mencionado parece ser o mais acertado, pois não há razão para que o Ministério Público tenha de atuar também na qualidade de fiscal da lei em um processo do qual já é autor e que, portanto, já está apto a fiscalizar e detectar qualquer irregularidade.

\footnotetext{
${ }^{17} \mathrm{CF} / 88$, Art $127, \S 1^{\text {â}}$. São princípios institucionais do Ministério Público a unidade, a indivisbilidade e a independência funcional"; $\S 2^{\mathrm{a}}$ : "Ao Ministério Público é assegurado autonomia funcional e administrativa podendo [...].

18 STJ. ReEsp. N. ${ }^{2}$ 184.906/SP, DJU 29.11.1999, 1ํㅡㄹ Turma, Rel. Min. Humberto Gomes de Barros. EMENTA:Processual - Ministério Público atua como parte- Parecer Desnecessário - Atuações Sucessivas - Prequestionamento a Posteriori - Impossibilidade Lógica - Posquestionamento - Recurso Especial Qucstão Constitucional - Conhecimento Impossível. I- Não faz sentido tomar parecer do Ministério Público, nos processos em que este atua como parte. II- Não se pode afirmar nulidade por falta de intimação do Ministério Público, se os respectivos agentes atuaran en todos os atos do processo. [...]
} 


\section{Ministério Público em caso de abandono ou desistência}

O $\S 3^{3}$ do artigo $5^{\text {a }}$ da Lei n. ${ }^{\text {a }}$ 7.347/85 dispõe que: "em caso de desistência infundada ou abandono da ação por associação legitimada, o Ministério Público ou outro legitimado assumirá a titularidade ativa”.

A razão da inserção deste dispositivo pelo legislador, ao que tudo indica, é o de se evitar, mais uma vez, eventuais fraudes por meio de simulações ou conluio entre as partes.

Assim sendo, na hipótese de o Ministério Público assumir uma demanda originariamente ajuizada por uma associação que a tenha abandonado ou dela desistido sem qualquer fundamento, este passará a figurar como autor, o que ocorrerá por meio do instituto da sucessão processual, como explica Cândido Rangel Dinamarco:

Adquire-se a qualidade de parte no momento em que a pessoa passa a ter a titularidade acima descrita (independentemente do exercício efetivo dos poderes e faculdades, ou seja, independentemente da prática de atos do processo), o que acontece mediante quatro modos distintos: a) pela demanda (quem pratica o ato de iniciativa ganha, desde logo, a condição de demandante - autor, exeqüente); b) pela citação (com ela, o citado passa a ser réu, ou executado); c) pela intervenção espontânea (ingressando em processo pendente, o terceiro passa a ser parte da relação processual inicialmente constituída entre outras pessoas); d) pela sucessão (o sucessor, ou sucessores, passam a ocupar o lugar deixado pelo sucedido). ${ }^{19}$

Da mesma forma que o Ministério Público não está obrigado a ajuizar a ação civil pública, conforme exposto em item anterior, também não está ele obrigado a dar prosseguimento ao feito abandonado por uma associação.

Nesse sentido, Pedro da Silva Dinamarco traz a seguinte lição: "Quando a associação-autora desistir do processo de forma infundada, ou abandoná-la, o Ministério Público não estará obrigado a assumir a titularidade da demanda. Apenas quando, a seu exclusivo critério, houver interesse social é que poderá fazê-lo."20

As razões para essa conclusão são as mesmas expostas acima, ou seja, o Ministério Público é apenas um dos co-legitimados e, sobretudo, acobertado pelo princípio da independência funcional.

Mas é evidente que, se constatado que a ação se refere a assunto de manifesto interesse social evidenciado pela dimensão do dano ou relevância do bem jurídico a ser protegido, deverá o Ministério Público, na ausência de outro legitimado, tomar a iniciativa, assumir o pólo ativo da ação.

\footnotetext{
19 DINAMARCO, C. R. Litisconsórcio, 4ª edição, São Paulo: Malheiros, 1996, p. 22.

21) DINAMARCO, P. op. cit., p.232.
} 


\section{Ministério Público estadual e federal: litisconsórcio}

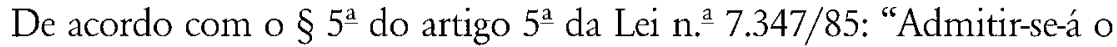
listiconsórcio facultativo entre os Ministérios Públicos da União, do Distrito Federal e dos Estados na defesa dos interesses e direitos de que cuida esta lei."

Antes da análise do dispositivo supracitado é importante destacar que o legislador acabou por gerar uma impropriedade terminológica, pois não haveria necessidade de ter se referido ao Ministério Público do Distrito Federal, uma vez que este já é compreendido pelo Ministério Público da União (art. 128, inciso I, alínea “d”, CF/88).

A redação do $\S 5^{a}$ do artigo $5^{a}$ da Lei n. ${ }^{a} 7.347 / 85$, como é sabido, foi inserida pelo artigo 113 do Código de Defesa do Consumidor, instituído pela Lei n. . 8.078/90.

Há uma certa polêmica acerca da vigência do aludido dispositivo, tendo em vista que o artigo $82 \S 2^{\mathrm{a}}$ da Lei n. $^{\mathrm{a}} 8.078 / 90$, que possuía a mesma redação do dispositivo ora em apreço, foi vetado pelo Presidente da República na sua atribuição constitucional no processo legislativo.

As razões do veto tinham como fundamento o disposto no artigo $128, \S 5^{\underline{a}}{ }^{21}$ da Constituição, que reserva à lei complementar a disciplina da organização e atribuições dos membros do Ministério Público.

Segundo Theotonio Negrão, o engano teria sido do órgão oficial que o publicou, pois na realidade, tanto o $\S 5^{\text {a }}$ do artigo $5^{\text {a }}$ da Lei n. $.^{\text {a }} 7.347 / 85$ como o $\S 2^{\mathrm{a}}$ do artigo 82 da Lei n. ${ }^{\mathrm{a}}$ 8.078/90 teriam sido vetados. E ainda aduz:

A publicação, no Diário Oficial, do texto vetado, como se estivesse sido aprovado, obviamente não pode trazer como conseqüência ser considerado em vigor, pois o Congresso jamais rejeitou o veto, que, portanto, ainda subsiste, à espera de ser aprovado ou rejeitado. ${ }^{22}$

Ao tratar do tema, José dos Santos Carvalho Filho revela:

Em nosso entender, apesar dessas observações, o dispositivo está em pleno vigor. Se o Chefe do Executivo, por descuido ou não, vetou determinado dispositivo e não o fez em relação ao outro de idêntico conteúdo, não há como deixar de considerar eficaz o dispositivo não vetado. Só com o veto expresso não se consuma por inteiro o ciclo da formação da lei. ${ }^{23}$

\footnotetext{
${ }^{21}$ Art. 128, § 5a: Leis complementares da União e dos Estados, cuja iniciativa é facultada aos respectivos Procuradores-Gerais, estabelecerão a organização, as atribuições e o estatuto de cada Ministério Público, obscrvadas, relativamente a seus membros: [...].

${ }_{22}$ NEGRÃO, T. Código de Processo Civil e legislação em vigor. 33a edição, São Paulo: Saraiva, 2002, p.999. ${ }_{2 i}$ CARVALHO FILHO, J. S. Ação Civil Pública: comentários por artigo. Rio de Janeiro: Freitas Bastos, 1995, p.126.
} 
Por outro lado, os argumentos no sentido de que o referido dispositivo não estaria em vigor em virtude de veto de dispositivo idêntico pelo então Presidente da República Fernando Collor, tornam-se frágeis. Isso porque, apenas dois meses antes da publicação do aludido artigo 113 do Código de Defesa do Consumidor, foi sancionado o artigo $210, \S 1^{\text {a }}$ do Estatuto da Criança e do Adolescente ${ }^{24}$ (lei ordinária tanto quanto a Lei n. ${ }^{-1}$ 8.078/90), cuja redação é praticamente a mesma daquele dispositivo vetado, a saber: "Admitir-se-á litisconsórcio facultativo entre os Ministérios Públicos da União e dos Estados na defesa dos interesses e direitos de que cuida esta Lei."

Ainda que superados os alegados vícios formais de constitucionalidade, boa parte da doutrina segue na discussão acerca da constitucionalidade desta modalidade de litisconsórcio sob seu enfoque material.

O primeiro argumento para a argüição de inconstitucionalidade da indigitada norma fundamenta-se na ofensa ao princípio federativo, uma vez que permite a participação do Ministério Público Federal em processos em trâmite na Justiça Estadual e vice-versa.

Há vozes na doutrina nos dois sentidos.

Pedro da Silva Dinamarco entende que a hipótese acima aventada não ofende o sistema federativo, sob o argumento de que a lei pode atribuir função diversa ao órgão do Ministério Público e de que isso não seria exclusivo da Lei da Ação Civil Pública, citando o seguinte exemplo: "Segundo o art. 37, inc. II e parágrafo, da Lei Orgânica do Ministério Público da União, para a defesa das populações indígenas, do meio ambiente e do patrimônto cultural o parquet federal pode atuar nas causas de competência de quaisquer juizes ou tribunais". ${ }^{25}$

Defendendo opinião contrária, Vicente Greco Filho acredita ser inconstitucional o sobredito dispositivo, alegando que:

É curial que a atuação do Ministério Público acompanhe a competência dos órgãos jurisdicionais perante os quais atuar. Assim, se a competência para o processo é da Justiça Federal, o Ministério Público estadual não pode atuar perante ela,e vice-versa. [...] lei ordinária não pode quebrar o sistema. Viola o parágrafo (em comento) o próprio sistema federativo, porque subverte as competencias das autonomias. ${ }^{26}$

\footnotetext{
24 Lei n. ${ }^{ \pm} 8069$, que dispóe sobre o Fstatuto da Criança e do Adolescente e dá outras providências de 13 de julho de 1990.

${ }^{25}$ DINAMARCO. op. cit., p.234.

In GRECO FILHO, Y. Comentarios ao Código de Proteçấo do Consumidor, art. 113, p. 377
} 
Un segundo argumento utilizado por aqueles que defendem a inconstitucionalidade material da previsão que permite o litisconsórcio entre "Ministérios Públicos" distintos alicerça-se nos princípios da unidade e indivisibilidade constitucionalmente assegurados ao Ministério Público.

Kazuo Watanabe, ao se pronunciar sobre o assunto, aduz que a autonomia de cada Ministério Público setorial, ou seja, o federal, o estadual, o militar etc., é apenas administrativa, uma vez que em termos institucionais trata-se de um órgão único, de âmbito nacional. $E$ acrescenta:

Desde que a defesa dos interesses e direitos difusos e coletivos esteja dentro das atribuições que a lei confere a um órgão do Ministério Público, a este é dado atuar em qualquer das Justiças, até mesmo em atuação conjunta, com o que se evitarão discussốes doutrinárias estéreis a respeito do tema e, mais do que isso, um inútil e absurdo conflito de atribuições, que não raro revela muito mais uma disputa de vaidades do que defesa efetiva da atribuição privativa de um órgão do Ministério Público. ${ }^{27}$

Nelson Nery Junior observa que, ao atuar, o Ministério Público está representando a sociedade, verdadeira titular do direito. E esta representação institucional é regulamentada pela lei. Diante disso argumenta que "na ausência de impeditivo legal, contudo, está o Ministério Público Estadual autorizado a, representando a sociedade, atuar na Justiça Federal ou na Justiça de qualquer Estado da federação, já que a unidade e indivisibilidade da instituição do parquet assim o permitem" ${ }^{28}$

Hugo Nigro Mazzilli afasta qualquer ofensa ao princípio de unidade e indivisibilidade do Ministério Público sob a alegação de que, não obstante a Constituição tenha reservado à lei complementar de cada Ministério Público a disciplina de suas atribuiçôes, organização e estatuto, isso não impediria que a lei federal ordinária desse outras atribuições aos seus membros ${ }^{29}$. Para sustentar seu posicionamento, tece o seguinte raciocínio:

Ora, os princípios da unidade e indivisibilidade do Ministério Público só valem dentro de cada instituição; não podem ser invocados para disciplinar a atuação de Ministérios Públicos de Estados diversos, ou a atuações destes em face da União, nem mesmo a atuação dos diversos Ministérios Públicos da União reciprocamente considerados, a não ser se tratássemos unidade e indivisibilidade sob o aspecto puramente abstrato. ${ }^{30}$

\footnotetext{
27 WAIANABE, $\mathrm{K}$ Codigo Brasileiro de Defesa do Consumidor comentado pelos autores do anteprojeto. $5^{2}$ ediçăo, São Paulo: Forense Universitária, 1998 , p.645.

24 NERY JUNIOR, N. Código Btasiteiro de Defesa do Consumidor conentado pelos autores do anteprojeto, $5^{3}$ ediçäo, São Pado; Forense Universtátia, 1998, p 798.

${ }^{2}$ MAZZOLYY, op. cit., 247

* Idem, Ibidem.
} 
João Batista de Almeida, ao contrário, entende ter sido correto o veto presidencial oposto, sob o fundamento de que os Ministérios Públicos da União e dos Estados têm sua atuação delimitada à Justiça Federal e Estadual, respectivamente. Neste sentido aduz:

Trata-se - é óbvio - de evidente cochilo no exercício do poder de veto, uma vez que as razões determinantes da extirpação do $\$ 2^{a}$ do art. 82 do CDC são as mesmas a fundamentar o veto do art. 113, que deu nova redação ao artigo da LACP, permitindo - por descuido, e só por isso - a volta do malfadado litisconsórcio, que ainda poderá ser excluído da legislação, se as autoridades envolvidas assim entenderem e se um novo projeto nesse sentido for aprovado e sancionado, ou ainda, se a tese passar a ser acolhida pelo Poder Judiciário." ${ }^{31}$

Ao ser questionado sobre assunto, José Carlos Barbosa Moreira expõe o seu entendimento da seguinte forma:

Inclino-me pela solução que atribui a cada ramo do Ministério Público atuar dentro de seu âmbito próprio e normal, isto é, o Ministério Público da União atua junto à Justiça Federal; o Ministério Público Estadual, junto à Justiça Estadual. É o que parece mais consentâneo com a estrutura do próprio órgão, não obstante essa unidade, que não exclui a diversidade, a distinção. Então, a mim me parece que cada ramo do Ministério Público tem seu âmbito de atuação. ${ }^{32}$

Respeitados todos os posicionamentos acima expostos, considera-se em plena vigência o $\S 5^{\text {a }}$ do artigo $5^{\text {a }}$ da Lei $n .^{\underline{a}} 7.347 / 85$, que veio a possibilitar a atuação conjunta dos membros de Ministérios Públicos correspondentes a órgãos administrativos diversos, como, por exemplo, do Ministério Público Federal com o Ministério Público Estadual. Tampouco existe qualquer vício de constitucionalidade, seja material, seja formal, quanto ao aludido dispositivo de lei.

$\mathrm{Na}$ realidade, ao que parece, a discussão doutrinária acerca do dispositivo ora em comento, dada a devida vênia, não tem razão de ser. A atuação conjunta do Ministério Público Federal e Estadual não afronta o princípio federativo ou mesmo o princípio da unidade e da indivisibilidade do Ministério Público.

\footnotetext{
:1 ALMEIDA, J. B. Aspectos Controvertidos da Ação Civil Pública. São Paulo: Revista dos Tribunais, 2001, p.104.

${ }^{32}$ MOReIRA, J. C. B. Ação Civil Pública. Revista Trimestral de Direito Público n. ${ }^{a}$ 93, p.200.
} 
O que ocorre nessa hipótese, por analogia, é o mesmo que ocorre quando dois advogados que receberam procuração de um mesmo cliente assinam conjuntamente uma petição inicial. Bastaria que um só a assinasse para que a demanda tivesse validamente sua distribuição (salvo se houvesse cláusula no mandato exigindo representação em conjunto), mas nada impede que ambos atuem conjuntamente e assinem igualmente a peça processual inicial.

Seguindo esse raciocínio, o fato de o legislador tratar da atuação conjunta do Ministério Público Estadual e Federal como hipótese de litisconsórcio é que afigura-se equivocada. Como já argumentado, o Ministério Público apenas é dividido administrativamente, mas institucionalmente é um único órgão, razão pela qual torna-se flagrantemente impróprio tratá-los como litisconsortes.

Sem o extremo rigor da terminologia técnico-juridica inerente ao direito positivo, dotado de imperfeições e atecnias típicas de todos os textos legais, deve-se simplesmente interpretá-lo e aplicá-lo consoante entendimento acima, e não simplesmente tratá-lo como inconstitucional, principalmente tendo em vista a relevância e os beneficios advindos de sua manutenção no ordenamento jurídico vigente.

Assim, não se trata, em verdade, de litisconsórcio de Ministérios Públicos, mas de um único Ministério Público representado processualmente por dois órgãos distintos: um Promotor de Justiça e um Procurador da República, o que parece plenamente possível, seja na justiça estadual, seja na federal.

\section{Conclusão}

1. O Ministério Público poderá ajuizar ação civil pública para tutelar direitos coletivos, difusos ou individuais homogêneos, estes últimos, apenas quando forem indisponiveis ou ostentarem relevante caráter social.

2. O Ministério Público não está obrigado ao ajuizamento da ação civil pública diante de uma situação fática potencialmente ejetora de um direito coletivo lato sensu em virtude dos princípios constitucionais da independência funcional e da autonomia. Por outro lado, uma vez ajuizada, a demanda passa a ser indisponivel, sendo vedada a sua desistência. 
3. Quando o Ministério Público for autor da ação civil pública não precisará atuar no processo na condição de fiscal da lei, eis que, ao integrar a relação processual, se encontra apto a fiscalizar e detectar qualquer irregularidade no processo, atribuições que teria na condição de custos legis.

4. Há impropriedade técnico-jurídica em relação ao litisconsórcio entre Ministério Público da União e Ministério Público dos Estados nas demandas coletivas, mas tal atecnia terminológica do legislador (artigo $5^{-}$, $\S 5^{\text {a }}$, Lei n. ${ }^{\text {a }}$ 7.347/85) não impede que um Promotor de Justiça e um Procurador da República assinem conjuntamente uma petição inicial de ação civil pública, seja perante a Justiça Estadual, seja perante a Justiça Federal.

\section{BIBLIOGRAFIA}

ALMEIDA, João Batista. Aspectos Controvertidos da Ação Civil Pública. São Paulo: Revista dos Tribunais, 2001.

CARVAlHO FILHO, José dos Santos. Ação Civil Pública: comentários por artigo. Rio de Janeiro: Freitas Bastos, 1995.

DINAMARCO, Cândido Rangel. Litisconsórcio, 4⿳a edição, São Paulo: Malheiros, 1996.

GRECO FILHO, Vicente. Comentários ao Código de Proteção do Consumidor, art. 113.

MAZZILLI, Hugo Nigro. A defesa dos interesses difusos em juízo. $13^{\mathrm{a}}$ edição, São Paulo: Saraiva, p.2001.

MOREIRA, José Carlos Barbosa. Ação Civil Pública. Revista Trimestral de Direito Público n. 93.

NERY JUNIOR, Nelson. Código Brasileiro de Defesa do Consumidor comentado pelos autores do anteprojeto, $5^{\mathbf{a}}$ edição, São Paulo: Forense Universitária, 1998.

NEGRÃO, Theotonio. Código de Processo Civil e legislação em vigor. 33 $3^{\mathrm{a}}$ edição, São Paulo: Saraiva, 2002.

WAMBIER, Luiz Rodrigues. Liquidação de Sentença. São Paulo: Revista dos Tribunais, 1997. 
WATANABE, Kazuo. Código Brasileiro de Defesa do Consumidor comentado pelos autores do anteprojeto. $5^{\mathrm{a}}$ edição, São Paulo: Forense Universitária, 1998.

ZAVASCKI, Teori Albino. O Ministério Público e Ação Civil Pública. Revista n. ${ }^{\underline{2}} 114$, ano 29, 1992. 